\title{
Observations on Upper Devonian acritarch communities from the southern Bergisches Land (Rhenish Massive)
}

\author{
ULRICH JUX \\ Department of Geology, University of Cologne, Zülpicher Straße 49, D-5000 Köln, F.R.G.
}

\begin{abstract}
In the southern Bergisches Land the Upper Devonian sequence (Frasnian and Lower Famennian) consists mainly of shales, marls and bituminous limestones together with an intercalated biostrome. The acritarch communities identified from these rocks are essentially characterised by members of the Micrhystridium-Veryhachium group.

Sections through the vesicle of Micrhystridium vulgare Stockmanns \& Willière reveal a simple, dense wall structure, but in the living cyst an exchange of gases was achieved through fine axial canals in its slender spines.

Abundance and diversity of the acritarchs increased off-reef and reflect both the palaeogeography and the depth.

The stable environments on the open marine shelf favoured phytoplanktonic life and also the formation of source rocks for hydrocarbons.
\end{abstract}

\section{INTRODUCTION}

Upper Devonian sediments are restricted in the southern Bergisches Land to the syncline of Bergisch Gladbach-Paffrath near Cologne (Fig. 1). There, the sequence consists of an uninterrupted Frasnian succession, overlain by the Lower Famennian Knoppenbießen formation. Unlike the Givetian sequence of the area, biostromes composed of corals and stromatoporoids, are relatively unimportant, occurring only in the Refrath Formation, the Upper Plattenkalk Formation which underlines the Refrath Formation consists of lagoonal limestones.

A rather sudden break in the facies at the top of the Refrath Formation is indicated by an abrupt increase in the clay components in the rock and a striking decline in benthic organic remains. Goniatites and cricoconarids are abundant in the succession overlying the Tonschiefer Formation, but in the Knoppenbießen Formation cricoconarids have disappeared.

Obviously, the bathymetric conditions had radically changed during the Frasnian and, as a result, the littoral invertebrates, in particular the rich reef associations, disappeared. Sedimentation in a neritic, insufficiently ventilated, yet full marine enviroment is recorded by some $150 \mathrm{~m}$ of claystones, shales, marls and bituminous limestones. This sequence has yielded an interesting microflora (Jux, 1975; Amirie, 1984) stimulating the following palaeobathymetric and palaeoecological interpretations of acritarach communities.

\section{FOSSIL PHYTOPLANKTON}

Among abundant sporomorphs, only a few acritarchs were recorded in samples from the Lower and Middle
Devonian of the Bergisches Land (Edalat, 1974; Hamid, 1974), and this sparseness agrees with the palaeogeographic situation. Marginal marine deposition of terrigenous clastics gradually waned, however, to be replaced by mainly bioconstructed limestones. An accelerated rate of subsidence, no longer compensated by the growth of corals and stromatoporoids, set an end to the biostromes during the Lower Frasnian. However, the influx of continental material in suspension remained evident in all post-Refrath formations. Although sporomorphs are now encountered far less than acritarchs, they were probably derived from similar terrestrial sources to the detrital quartz $(\varnothing 0.01$ $0.06 \mathrm{~mm}$ ) within the shales and marls.

All the palynomorphs are perfectly preserved. A marked change in the assemblages of acritarchs is evident during the Upper Frasnian and Lower Famennian, coinciding with the disappearance of characteristic invertebrate groups (e.g.cricoconarids).

Almost no acritarchs were recorded from the Upper Plattenkalk and the Refrath Formations, while the number of species and individuals markedly increases in the Tonschiefer Formation, reaching a maximum in the Hombach Formation (Fig. 2). The 20 genera including some 80 species, meanwhile recorded (Jux,1975; Amirie, 1984) are arranged in reference to Downie's (1973) morphological groups:

1. Tasmanites group: Tasmanites Newton, Tapajonites Sommer \& van Boekel.

2. Sphaeromorph acritarchs: Leiosphaeridia Eisenack, Lophosphaeridium Timofeev. 
3. Pterospermopsis group: Tornacia Stockmanns \& Willière, Cymatiosphaera Wetzel, Dictyotidium Eisenack.

4. Baltisphaeridium group: ?Baltisphaeridium Eisenack, Hapsidopalla Playford.

5. Micrhystridium-Veryhachium group: Micrhystridium Deflandre, Multiplicisphaeridium Staplin, Stellinium Jordan et al.,? Solisphaeridium Staplin et al., Polyedryxium Deunff, Veryhachium Deunff, ?Goniosphaeridium Eisenack, Elektoriskos Loeblich, Leiofusa Eisenack.

6. Visbysphaera group: Gorgonisphaeridium Staplin et al., Eisenackidium Cramer.

Among these, Leiofusa and Eisenackidium were only observed in samples from the Knoppenbießen Formation (Jux, 1975).

The rich assemblage of acritarchs, mainly represented by the Micrhystridim-Veryhachium group, includes typical Upper Devonian fossils such as Micrhystridium adductum Wicander, M. alperni (Stockmanns \& Willière), M.complurispinosum Wicander, M.elongatum (Wicander), M.formosum (Stockmanns \& Willière), M.kufferathi Stockmanns \& Willière, M.lejeunei
Stockmanns \& Willière, M.pascheri Stockmanns \& Willière, M.spinoglobosum Staplin, M.tornacense Stockmanns \& Willière, M.vulgare Stockmanns \& Willière, Multiplicisphaeridium ramusculosum (Deflandre), Polyedryxium micropolygonale (Stockmanns \& Willière), Tornacia stela Wicander, Cymatiosphaera chelina Wicander \& Loeblich C. platoloma Wicander \& Loeblich, C.rhacoamba Wicander, $C$. rhodana Wicander \& Loeblich. Dictyotidium fairfieldense Playford, Gorgonisphaeridium microsaetosum Staplin), G. separatum Wicander, and Eisenackidium martensianum Stockmanns \& Willière.

The rare acritarchs of the Upper Plattenkalk and Refrath Formations belong to the sphaeromorphs: Leisphaeridia minuta (Staplin), L. laevigata Stockmanns \& Willière. Tasmanitids first appear within the Tonschiefer Formation; they are widely distributed in the dark marls and limestones of the Hombach and Sand Formations. The increased number of identified species corresponds with a much higher quantity of fossilised prasinophycean cysts than in the Tonschiefer Formation (Fig. 2).

It is of particular interest that the rather monotonous

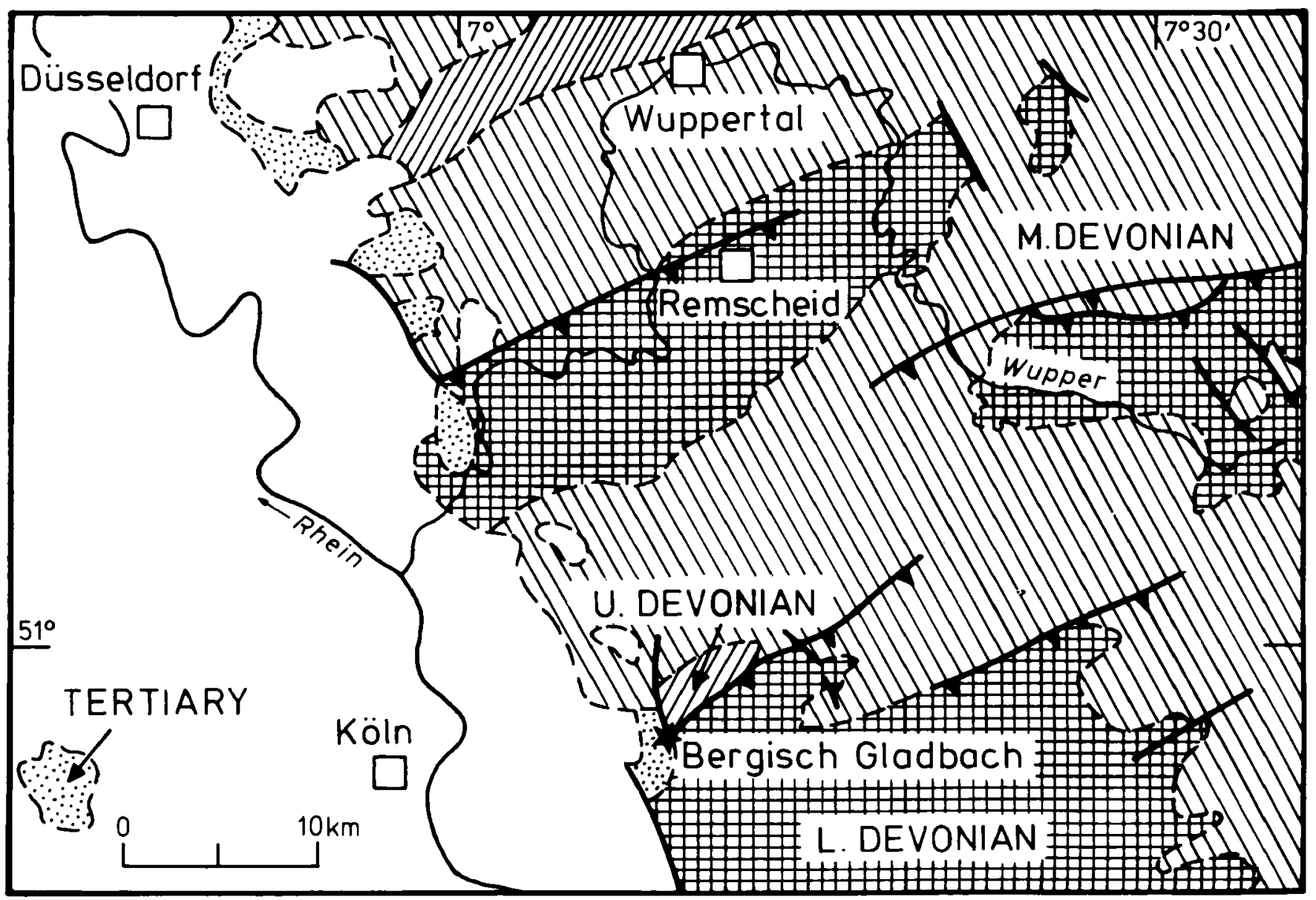

Fig. 1. Geological map of the Bergisches Land showing the location of the Bergisch Gladbach-Paffrath syncline. 

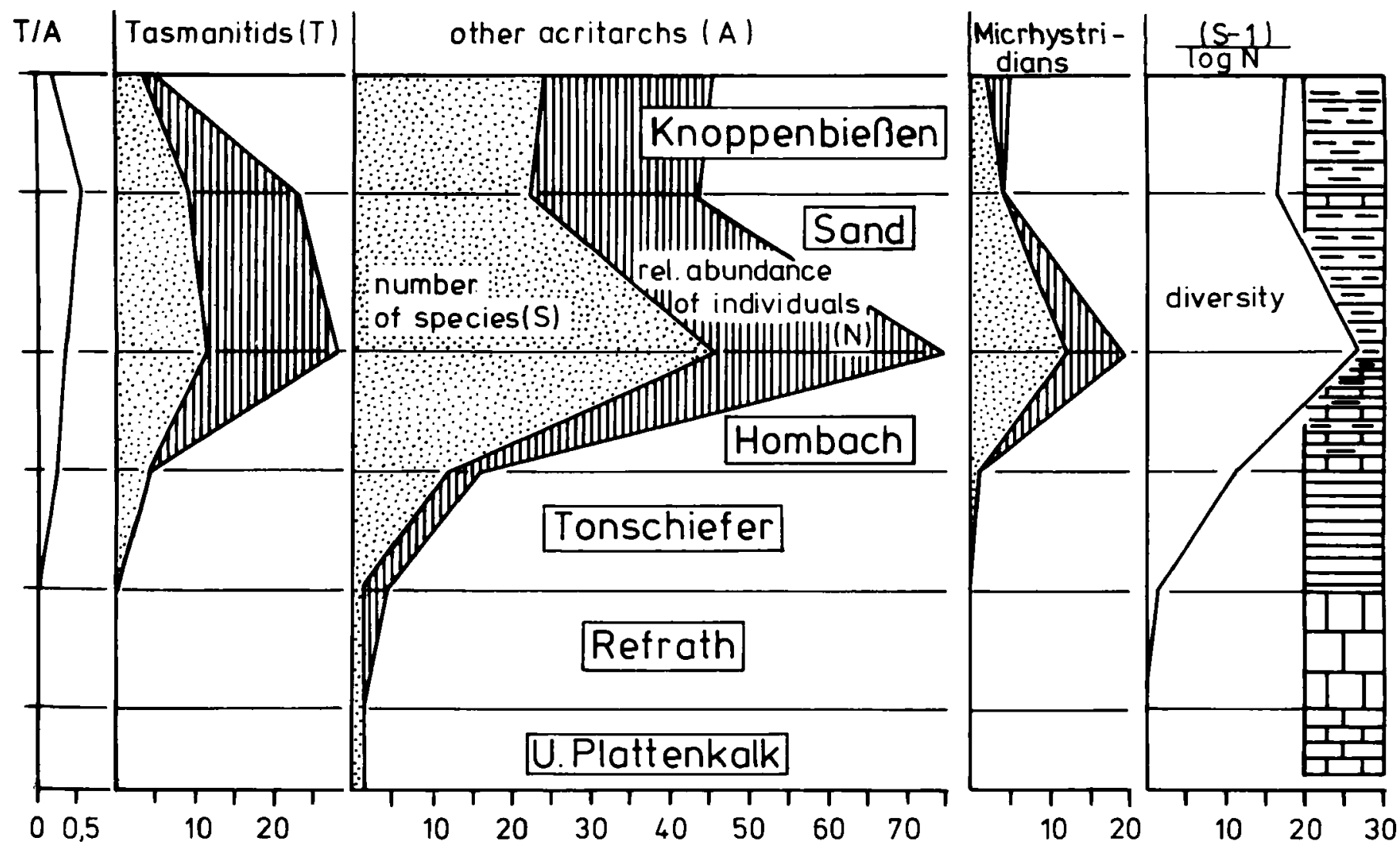

Fig. 2. Acritarchs in the Upper Devonian sequence of the southern Berisches Land.

shales of this formation yielded acritarchs (12 species), because megafossils (Lingula, Calvinaria, Buchiola, Homoctenus, Styliolina, Tornoceras, Manticoceras) are restricted to a few layers within the pelitic succession.

The number of acritarch species and their abundances culminate in the Hombach Formation, but rich asse mblages are also to be noted in the Sand and Knoppenbießen Formations (Jux, 1975; Amirie, 1984). The increasing diversity up the stratigraphic profile is echoed by the abundances of the Micrhystridium-Veryhachium group, represented by some 40 species (Fig. 2). Micrhystridium alone is represented by 14 species.

\section{MICRHYSTRIDIUM VULGARE Staplin \& Willière}

This characteristic species was found abundantly in the Hombach and Knoppenbießen Formations (Jux, 1975; Amirie, 1984) and can be taken as a typical representative of the Micrhystridium-Veryhachium group $(\mathrm{Pl} .1$, figs.1,4). From a rounded body $(\varnothing 15-20 \mu)$ some 10-15 projections emerge like whipcords from expanded bases. The finely granulated sculpture appears to be almost smooth (PI. 1, figs.3,6). Most of the specimens are flattened by compaction of the sediment. The epityches show that nearly all specimens were deposited after excystment (Pl. 1, fig. 4).

Some of the capsules seem to have perforated walls (PI. 1, fig. 5). In fact, Veryhachium downiei Stockmanns \& Willière, a species well noted in the Hombach and Sand Formations but most abundant in the Knoppenbießen Formation, has definite radial pores which penetrate the wall of the body and emerge through fine outer granules (Jux, 1975, Pl. 6, fig. 1). Therefore, the question is whether or not $M$. vulgare has a tasmanitid wall structure.

Sections through several specimens, however, clearly demonstrate that the wall of the spinose body is rather simply constructed. It certainly lacks radial pores (PI. 1, figs. $7,10,11$ ) and the scarred surface of some cysts, as shown in Pl. 1, fig. 5, is actually caused by corroded crystals of pyrite. Mineralisation occurred during early diagenesis in an insufficiently oxygenated depositional environment, thus minute crystals of pyrite can also be found inside the capsules (Pl. 1, fig. 9). This is very similar to the preservation of the contemporaneous megafossils (e.g. goniatites).

Nevertheless, the living cyst of $M$. vulgare was not completely sealed. Sections through the spines show that they are penetrated by an axial canal. This vein-like 
structure leads from the body cavity into the proximal part of the process (Pl. 1, fig. 11). The diameter of the vein decreases along its length (PI. 1, figs. 7,8). At the tip of the spines (Pl. 1, figs. 2,3,6) the canal emerges, but the small opening is hardly visible.

\section{DISCUSSION}

Acritarch assemblages described from the Frasnian of Belgium (Stockmanns \& Willière, 1960, 1969) are similar in composition to those from the Bergisches Land in spite of the fact that the regional lithofacies are dissimilar. Bioconstructed reef limestones disappear in the Bergisches Land with the deposition of the Refrath Formation whereas the corresponding F2d bioherm of Belgium is overlain by F2e,f shales. The F2d bioherm is the most likely time-equivalent to the Tonschiefer and Hombach formations (Calvinaria formosa) of the Bergisches Land and is succeeded in Belgium by two other reef intervals (F2h and F2j). There, the Matagne Formation, which only partly replaces the Sand formation, indicates the final disappearance of Devonian reef limestones. Dricot (1967) found that acritarch associations near reefs were dominated by spinose specimens, mainly belonging to micrhystridians. Off reef associa- tions on the other hand, were dominated by sphaeromorphs, mainly belonging to leiosphaeridians and lophosphaeridians. The repeated change in the rate of subsidence controlled the lithofacies and also must have caused fluctuations in the composition of acritarch assemblages, stemming either from deep open or from shallow restricted water bodies.

In the region of Bergisch Gladbach, only one reef event is recorded during the Upper Devonian and the extinction of corals and stromatoporoids is soon followed by a bloom of micrhystridians. The highest species diversity and maximun abundance of acritarchs is recorded in the overlying Hombach Formation (Fig. 2). The gradual transgression and deepening of the Devonian sea is also reflected in syngenetic calcareous concretions, by a shift from light to heavy ${ }^{13} \mathrm{C} /{ }^{12} \mathrm{C}$ combinations (Jux \& Manze, 1974). In the Upper Devonian sequence this trend is even better indicated by the diversity pattern of the phytoplankton. The rigorous and variable conditions on the reefs (Refrath Formation) and in the lagoons (Upper Plattenkalk Formation) considerably restricted living conditions of acritarchs. Only a few populations of sphaeromorphs (Leiosphaeridia, Lophosphaeridium) seem to have adjusted to thrive and to excyst there. Towards the open

\section{Explanation of Plate 1}

Micrhystridium vulgare Stockmanns \& Willière, 1962

Upper Devonian (Frasnian) Homkbach Formation, Bergisch Gladbach, Sand.

Fig. 1. Slightly compressed specimen. SEM image; scale bar $=10 \mu \mathrm{m}$.

Fig. 2. Section through a spine; axial canal barely visible. TEM image $(19582 ; 62390-\mathrm{F} 2$;B 181$)$; scale bar $=1 \mu \mathrm{m}$.

Fig. 3. Surface of a capsule with fine granulation. SEM image; scale bar $=3 \mu \mathrm{m}$.

Fig. 4. Complete specimen with epityche. SEM image; scale bar $=10 \mu \mathrm{m}$.

Fig. 5. Part of a cyst with epityche; porosity of wall is due to corroded pyrite crystals. SEM image; scale bar $=3 \mu \mathrm{m}$.

Fig. 6. Part of a cyst with epityche; surface sculptured by fine granules. SEM image; scale bar $=10 \mu \mathrm{m}$.

Fig. 7. Section through a cyst with attached spine; note axial canal. TEM image $(13575 ; 62390-E 5 ; B$ 184); scale bar $=3 \mu \mathrm{m}$.

Fig. 8. Cross-section of a spine; note axial canal. TEM image $(13579 ; 62390-\mathrm{F} 1 ; \mathrm{B} 184)$; scale bar $=1 \mu \mathrm{m}$.

Fig. 9. Section through a mineralised cyst; accretions of pyrite within the wall and the inside of the cyst. TEM image $(13594 ; 62390-\mathrm{G} 4 ; \mathrm{B} 178)$; scale bar $=3 \mu \mathrm{m}$.

Fig. 10. Enlarged section through the wall; note simple structure. TEM image $(13564 ; 62390-E 2 ; B$ 184); scale $b a r=1 \mu \mathrm{m}$. 


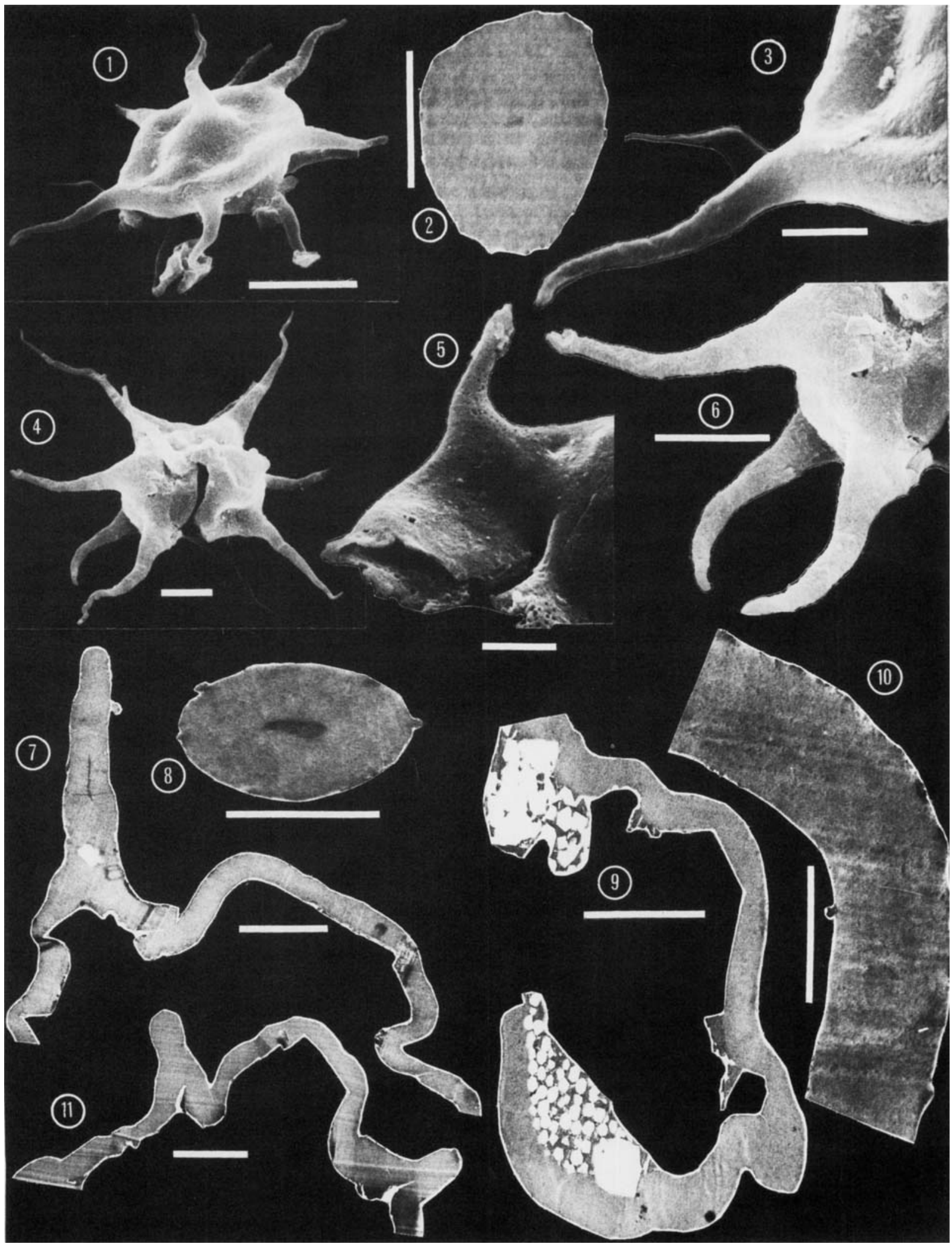


marine shallow shelf with its more stable environment, species diversity noticeably increased (Fig. 2).

The highly alate or spinose vesicle surfaces of the majority of the specimens aided buoyancy in warm equatorial waters (Jux, 1975), whereas the various wall structures with penetrating pores or delicate canals are thought to be bathymetric adaptations for the control of hydrostatic pressures.

From the tropical diversity of the acritarch associations a high rate of biogenic productivity can be concluded. This is also reflected in the dark, bituminous limestones and shales of the Upper Devonian section in Bergisch Gladbach. In this facies, fossil nekton and plankton both accumulated considerably. No doubt, the Hombach-Formation, and to a minor degree also the Upper Plattenkalk, Sand and Knoppenbießen Formations, are potential source rocks for hydrocarbons (Jux \& Zygojannis, 1983). Considering regional tectonic structures and the reef carbonates as potential traps for gas and oil, the restriction of Upper Devonian sediments to just a small area in Bergisch Gladbach, reduces economic prospects to a minimum. Nevertheless, Upper Devonian hydrocarbons are shown to be mature by a relatively low carbonisation level (Vitrinit Rmax: $0.69 \%$ ) and by the presence of oil shows in all of the mentioned formations (Jux, 1956; Jux \& Krath, 1974; Jux \& Zygojannis, 1983).

\section{ACKNOWLEDGMENTS}

The author is indebted to Dr. G.H.B. Amirie for placing several isolated specimens of Micrhystridium vulgare at his disposal and to Mr. W. Mackowiak for preparation of both S.E.M. and T.E.M. images.

\section{REFERENCES}

Amirie, G. H. B. 1984. Phytoplankton aus dem Frasne des Bergischen Landes, Rheinisches Schiefergebirge. Sonderveröffentlichungen Geol. Inst. Köln, 49, 1-99.

Downie, E. M. 1967. Observation on the nature of the acritarchs. Palaeontology, London, 16 (2) 239-259.

Dricot, E. M. 1967. Evolution et distribution paléogeographique du microplancton (Acritarches) dans le Frasnien de la Belgique. Int. Symp. Devon. Syst.: Alberta Soc. Petrol. Geol. Calgary, 2, 855-859.

Edalat, B. 1974. Sporenvergesellschaftungen und Acritarchen aus dem Unterdevon (Ems) des südlichen Bergischen Landes (Rheinisches Schiefergebirge). Sonderveröffent. lichungen Geol.Jnst.Köln, 24, 1-75.

Hamid, M. E. P. 1974. Sporenvergesellschaftungen aus dem unteren Mitteldevon (Eifel-Stufe) des südlichen Bergischen Landes (Rheinisches Schiefergebirge). N.Jb. Geol. Paläont., Abh., Stuttgart, 147, (2), 163-217.

Jux, U. 1956. Stratigraphie, Faziesentwicklung und Tektonik des jüngeren Devons in der Bergisch Gladbach-Paffrather Mulde. N.Jb. Geol. Paläont., Abh. Stuttgart, 102, (3), 295-328.

Jux, U. 1975. Phytoplankton aus dem mittleren Oberdevon (Nehden-Stufe) des südwestlichen Bergischen Landes (Rheinisches Schiefergebirge). Palaeontographica, B, Stuttgart, 149, (5-6), 113-138.

Jux, U. \& Manze, U. 1974. Milieu-Indikationen im Devon des Bergischen Landes mittels Kohlenstoff-Isotopen. N.Jb. Geol. Paläont., Mh.,Jg., Stuttgart, 6, 353-373.

Jux, U. \& Krath, J. 1974. Die Fauna aus dem mittleren Oberdevon (Nehden-Stufe) des südwestlichen Bergischen Landes (Rheinisches Schiefergebirge). Palaeontographica, A, Stuttgart, 147, (4-6), 115-168.

Jux, U. \& Zygojannis, N. 1983. Kohlenwasserstoffe und isotopische Zusammensetzung oberdevonischer Karbonatgesteine (Oberer Plattenkalk) der Bergisch GladbachPaffrather Mulde (Bergisches Land). N.Jb. Geol. Paläont., Abh., Stuttgart, 167, (1), 89-131.

Stockmanns, F. \& Willière, Y. 1960. Hystrichosphères du Dévonien belge. Senck. leth., Frankfurt, 41, 1-6, 1-11.

Stockmanns, F. \& Willière, Y. 1969. Acritarches du Famennien Inférieur. Acad. Royale de Belgique, Cl.Sc., Mem., Coll. Bruxelles, No. 8 (2), 38, (6), 1-63. 